\title{
The Belt and Road Initiative From A Supply-Chain Trade and Trade Facilitation Perspectives in Malaysia
}

\author{
Au Yong Hui Nee \\ Faculty of Business and Finance \\ Universiti Tunku Abdul Rahman \\ Kampar, Malaysia \\ auyonghn@utar.edu.my
}

\begin{abstract}
Over the past decades, bilateral relations have deepened and trade soared between Malaysia and China. China has become Malaysia's largest trading partner in the last decade. Now, the two countries are more closely linked. Hence, this study attempts to look into the past achievement particularly in enhancing the ties between Malaysia and China in trade and investment. These policy initiatives are analyzed with connections to multinational corporations (MNCs) strategies and governments' developmental objectives in Malaysia. Recommendations are drawn not only for Malaysia but for other developing nations.
\end{abstract}

Keywords-ASEAN; Chinese outward FDI; Economic Globalization; Foreign Direct Investment; Global Capitalism

\section{INTRODUCTION}

Malaysia as an open economy, ranked as top $25^{\text {th }}$ largest exporting nations in the world [1]. Malaysia was placed 15th spot in the A.T. Kearney 2014 Foreign Direct Investment Confidence Index ranking. In the World Bank's Doing Business Report 2019, Malaysia is placed at 15th out of 190 countries. The Malaysian economy is estimated to attain a per capital gross domestic product (GDP) of USD 20,000 by 2025 , with total GDP exceeding \$1 trillion by 2030. The economic structure of the Malaysia will continue to shift towards higher value-added manufacturing and services. Strategic growth industries in the services sector will include financial services, health care, education, commercial aviation, tourism and global business services (GBS) industry. Malaysia, named as Asia's Next Advanced Economy, becomes an increasingly important services-exporting economy in Southeast Asia [2]. This study is to review and shed lights on the spill-overs from economic contributions on Malaysia-China bilateral trade policies and the economic globalization of Chinese Foreign Direct Investment (FDI) into Malaysia. This paper uses information from secondary sources, to analyze investments in Malaysia from China firms. Data was collected through written documents which include newspapers, magazines, websites, and others. The contents of these documents were analyzed.

\section{A. Malaysia-China Relations}

Amid fears of communism in Southeast Asia, Malaysia is the first Southeast Asian nation to establish diplomatic relations with China in 1974. China expressed its appreciation to Malaysia in the Joint Communique between China and Malaysia in Conjunction with the 40th Anniversary of the Establishment of Diplomatic Relations, for Malaysia was the first country of ASEAN to establish diplomatic relations with China and played an instrumental role in bringing China into the ASEAN as a Dialogue Partner. Now, Malaysia and China are even more closely connected. China has been Malaysia's largest trading partner since 2009, and Malaysia is one of China's most important trading partners among ASEAN. The breakthrough was in 2009 when the former Chinese President $\mathrm{Hu}$ Jingtao visited Malaysia. Another breakthrough in 2013 with the visit of Chinese President, Xi Jinping. Malaysia and China signed the 5-Year Development Programme for Economic and Trade Cooperation (2013-2017) plan for an ambitious bilateral trade of USD160 billion by 2017 [3].

\section{B. Belt and Road Initiative Summit on 14 May 2017}

China President Xi Jinping launched the belt and road initiative in 2013. On 14 May 2017, China held the first One Belt One Road summit to spur the implementation of the initiative. The Malacca Straits has been an important shipping lane in the past 2,000 years. Malaysia was ranked 25th in the World Economic Forum [4] Global Competitiveness Index 2018-2019. On quality of overall infrastructure, Malaysia was ranked 22nd in the world, or second behind Singapore in ASEAN. 


\section{Second Belt and Road Economic Cooperation Forum for International Cooperation on 26 April 2019}

On 26 April 2019, China held the Second Belt and Road Forum for International Cooperation, participated by 37 heads of states and governments, to stimulate the initiative's implementation. China President Xi Jinping said the Belt and Road projects should uphold the principle of shared benefits and joint contributions. Malaysian Prime Minister Mahathir Mohamad attended the global infrastructure investment program. He expressed his fully support to the Belt and Road Initiative and that Malaysia would benefit from the projects. Reported in the New Straits Times [5], China's AI unicorn SenseTime partner with G3 Global will build a US\$1 billion AI park, the first AI Park in Malaysia, where SenseTime will provide technology expertise to G3, while also working with it to develop educational materials.

\section{Malaysia and China Bilateral Trade}

China-ASEAN bilateral trade between had grown about 35 times from US\$9 billion in 1991 to US\$346 billion in 2015. Malaysia has been China's largest trading partner in South East Asia since 2009. Chin-Malaysia bilateral trade recorded RM313 billion in 2018 with an annual growth rate of 8 per cent. Malaysia's trade deficit with China has increased over the years. The main imports recorded are such as appliances and parts, while exports to China include commodities such as palm oil, minerals, petroleum and gas. China is Malaysia's largest import source.

According to eMarketer, retail e-commerce sales in the Asia-Pacific region grew more than 30 percent in 2017 to $\$ 1.35$ trillion; China accounts for almost 83 percent of the ecommerce sales in the region [6]. Furthermore, 60 cents of every dollar spent online globally will come from China by 2020 [7].

Furthermore, Bank Negara Malaysia [8] and the People's Bank of China has agreed to renew for the third time the bilateral currency swap arrangement with a size of RMB180 billion/RM110 billion for a further tenure of three years. The agreement renewal proves continuous commitment in promoting the practice of local currencies for settlement of Malaysia and China bilateral trade and direct investment.

\section{E. Manufacturing Investments in Supply Chain}

China has historically emphasized FDI, however, the policy has undergone a major shift that encouraging Chinese companies to go abroad. BRI outlined by Beijing in 2013 was a key feature of this promotion of ODI. China's accumulated investments in Malaysia only amounted to US\$1 billion in 2013 compared with Malaysia's US\$7 billion in China.

Malaysia is an alternative source of manufactured goods and imports. Business relocation and investment diversion of China manufacturers in Malaysia is important at a time when the global supply chain is undergoing significant reorientation due to the China-US trade tensions. China-U.S. trade tensions provide Malaysia with opportunities to attract investment and increase exports investments.

Global real estate consultancy Knight Frank in its latest research report titled "New Frontiers: Prospects for Real Estate Along the Belt and Road Initiative", Malaysia is the only other Southeast Asian country to make the 9th ranked to the top 10 of the Knight Frank Belt and Road Index (BARI); and Malaysia has received the largest amount of investments from China of all the countries in Southeast Asia over the past 10 years [9]. Malaysia has received large amounts of investments from China and is among the BRI's biggest supporters in Southeast Asia.

By the end of 2018, a total of 422 manufacturing projects with participation from China were implemented, creating 73,000 jobs in Malaysia. China's investments in local manufacturing from 2009 to 2018 totaled RM41.9 billion. China is becoming more prominent in recent years due to its policy of encouraging investments abroad.

Since the announcement of the Belt and Road Initiative, FDI from China has bounced from RM3 billion in 2013 to RM20 billion in 2018, while FDI from the US has reduced from RM6 billion to RM3 billion for the same period.

TABLE 1 CHINA AND US APPROVED MANUFACTURING INVESTMENTS IN MALAYSIA

\begin{tabular}{|c|c|c|}
\hline \multicolumn{2}{|c|}{ INVESTMENTS IN MALAYSIA } \\
\hline 2009 & $\begin{array}{c}\text { China FDI } \\
\text { (Billion RM) }\end{array}$ & $\begin{array}{c}\text { USA FDI } \\
\text { (billion RM) }\end{array}$ \\
\hline 2010 & 0.162 & 2.345 \\
\hline 2011 & 0.640 & 11.739 \\
\hline 2012 & 1.194 & 2.509 \\
\hline 2013 & 1.978 & 0.296 \\
\hline 2014 & 3.018 & 6.321 \\
\hline 2015 & 4.751 & 1.350 \\
\hline 2016 & 1.872 & 4.150 \\
\hline 2017 & 4.775 & 1.400 \\
\hline 2018 & 3.854 & 1.107 \\
\hline
\end{tabular}

China was the manufacturing sector's biggest investor (for the third consecutive year) in 2018, followed by Indonesia, the Netherlands, Japan and USA, and jointly accounted for $76 \%$ of the total foreign investments approved. Most of these involved the production of high-technology, high-value-added goods. One of the noteworthy China projects approved in 2018 was RM1 billion investment from Jinjing Technology Malaysia to produce float glass that will be supplied to solar companies in Malaysia, Vietnam, and the US [10]. Malaysia is the world's third largest solar cell and module manufacturer.

Guangxi Beibu Gulf Iron and Steel Co Ltd has invested RM4.2 billion inn Alliance Steel, Kuantan, and Hebei Xinwuan Steel Group has also invested RM13 billion in an 
integrated steel-making complex in Samalaju Industrial Park, Bintulu, Sarawak.

An example of impact project is the RM400 million China Railway Rolling Stock Corp (CRRC) established in 2015 that will materialize the plan for Malaysia becoming the ASEAN rail manufacturing hub. About 85 per cent of its workers are locals, some are trained in China and hold high positions in the company [11].

In the automobile manufacturing, Foshan Feichi Automobile Manufacture Co. Ltd to provide expertise to produce hydrogen fuel as an energy and for export in Sarawak [12]. Another example of successful collaboration is Proton. In 2017, Zhejiang Geely Holding Group controls a 49.9\% equity stake in Proton, and the latter will set up of a US\$30 million manufacturing assembly plant in Pakistan, being a symbolic of the Belt and Road Initiative [13].

\section{DISCUSSION}

The Malaysian government has strongly emphasized the possibilities of spillovers to be generated by multinational corporations. Policies adopted have aimed to maximize positive spillover effects of MNCs in various economic sectors. The internationalization strategies of Chinese firms were founded on cost-based competencies and other location-based advantages and aided by government Belt and Road Initiative. China invests sizeable funding in Southeast Asia's economic development offers opportunities for the host country increased national income generation.

It is about how a host country Malaysia can leverage on China's investment without losing the nation's interest. There are a few recommendations for the consideration of the decision-makers. First, Malaysia is trying to seek a balance between the two big powers of the world namely, the United States and China. Malaysia should actively pursue economic diversification strategies, in midst of uncertainty of the rise of trade protectionism and slow progress of Regional Comprehensive Economic Partnership (RCEP) and Comprehensive and Progressive Agreement for Trans-Pacific Partnership (CPTPP). Second, Malaysia offers unparalleled advantages for companies with a regional strategy. China's business community is encouraged to view Malaysia as the gateway to the enormous ASEAN Economic Community (AEC) and Organization of Islamic Cooperation (OIC) countries. Third, extra value-added for the regional actors can be attained through robust advocacy and facilitation of 'bottom-up' participation of local suppliers.

\section{CONCLUSION AND IMPLICATIONS}

According to National Development and Reform Commission [14], the Belt and Road Initiative is a way for win-win cooperation that promotes common development and prosperity. Limited market in Malaysia can be useful predictors for propensity of firms to engage in international expansion. Malaysia has to upkeep her competitiveness and transformation into a high value-added service economy to escape the middle income trap towards a trillion dollar economy. Malaysia can potentially benefit from manufacturing investments from China to access wider BRI markets. Therefore, the involvement and investment of China capital required careful implementation.

\section{REFERENCES}

[1] World Trade Organization. World Trade Statistical Review 2018. Geneva, Switzerland. 2018.

[2] IHS Markit. Emerging Markets in Asia Pacific Offer Brightest Prospects for Global FDI, IHS Study Finds. 2016, April 14.

[3] The Official Launch of Malaysia-China Kuantan Industrial Park. 2013.

[4] World Economic Forum. Global Competitiveness Index 2017-2018. 2017.

[5] G3 Global and Chinese firms to build AI Park in Malaysia. The New Straits Times. 2019, April 26. https://www.nst.com.my/business/2019/04/483219/g3global-and-chinese-firms-build-ai-park-malaysia

[6] Honeywell introduces WMS in Asia \& HGRs. Focus Malaysia. (2018, 4 October)

[7] Alibaba Offers Malaysian Merchants Access into China. BERNAMA. (2018, 29 March)

[8] Bank Negara Malaysia (BNM). Renewal of Bilateral Currency Swap Arrangement between Bank Negara Malaysia and the People's Bank of China. Press Releases Ref No: 08/18/07. (2018, August 20). http://www.bnm.gov.my/index.php?ch=en_press\&pg=en_ press\&ac $=4731$

[9] Khoo, N. Malaysia's industrial and logistics market to benefit from BRI. The Edge Property. 2019, May 11.

[10] Malaysian Investment Development Authority (MIDA). Malaysia Investment Performance Report 2018. 2019.

[11] Malaysia aims to venture into train manufacturing - Loke. The Star. (2019, January 3). http://www.bernama.com/en/news.php?id=1680988

[12] Win-win ties between China and Sarawak. Sarawak Tribune. (2018, October 1)

[13] Wong Ee Lin. Dr M witnesses exchange of documents for upcoming Proton plant in Pakistan. The Edge Markets. (2019, April 26)

[14] National Development and Reform Commission, PRC. Vision and Actions on Jointly Building Silk Road Economic Belt and 21st-Century Maritime Silk Road. 28 March 2015. 